Федина К. М. [1; ORCID ID: 0000-0001-5571-384X], к.е.н., доцент

${ }^{1}$ Національний університет водного господарства та природокористування, м. Рівне

\title{
ПРОБЛЕМИ ТА ШЛЯХИ ВДОСКОНАЛЕННЯ КАЗНАЧЕЙСЬКОЇ СИСТЕМИ КАСОВОГО ВИКОНАННЯ БЮДЖЕТІВ
}

У статті досліджено сутність Казначейської служби та їі основну роль в бюджетному процесі. Проаналізовано проблеми діяльності Державної казначейської служби. Запропоновано перелік заходів 3 покращення діяльності казначейської системи виконання бюджетів.

Ключові слова: фінансова політика; казначейська система; бюджет; Міністерство фінансів України; фінансова безпека; ЄКР; активи і пасиви.

В умовах фінансової нестабільності важливим є забезпечення надійності виконання основного фінансового плану - Державного бюджету України. Для забезпечення стабільності соціальноекономічного розвитку, потрібно вжити змін у сфері управління державними фінансами, зокрема в системі виконання державного та місцевого бюджетів. Даний процес є складним, а основну роль у ньому відіграє Державна казначейська служба України (ДКСУ).

Аналіз останніх досліджень. Про потребу в аналізі діяльності Державної казначейської служби та виявлення нових і удосконалення діючих шляхів розвитку казначейської системи виконання Державного бюджету написано багато наукових праць і інформаційних видань. Значні наукові доробки у даній сфері належать П. М. Боровику, І. М. Козловій, 0.О.Непочатенко [1; 2; 3]. Однак, незважаючи на вагомість зазначених напрацювань, недостатньо вирішеними залишаються питання 3 реформування казначейської системи України для створення відповідності між функціями, методами та повноваженнями казначейської служби України та покладеними на неї обов'язками на сучасному етапі.

Постановка завдання. Проаналізувати діяльність Державної казначейської служби для виявлення нових і удосконалення діючих шляхів розвитку казначейської системи виконання Державного бюджету України.

Виклад основного матеріалу. В Україні триває формування сучасної системи управління фінансами державного сектору економіки. При цьому враховується ринкова природа фінансів, у 
відповідному контексті відбуваються зміни у сфері дохідної й видаткової політики держави, боргової політики. Кінцевою метою започаткованих реформ $€$ наближення ефективності управління державними фінансами України до рівня розвинутих країн [3].

Казначейство відповідно до покладених на нього завдань:

- забезпечує казначейське обслуговування бюджетних коштів на основі ведення єдиного казначейського рахунку, відкритого у Національному банку;

- управляє наявними фінансовими ресурсами, що консолідуються на єдиному казначейському рахунку;

- здійснює безспірне списання коштів державного та місцевих бюджетів або боржників на підставі рішення суду;

- здійснює відкриття, закриття та обслуговування рахунків у системі електронного адміністрування податків;

- обслуговує кошти фондів загальнообов'язкового державного соціального і пенсійного страхування, інших клієнтів та кошти єдиного внеску на загальнообов'язкове державне соціальне страхування;

- веде бухгалтерський облік операцій з виконання державного та місцевих бюджетів;

- зводить і складає звітність про виконання державного, місцевих, зведених місцевих і зведеного бюджетів та подає звітність органам законодавчої, виконавчої влади, місцевим фінансовим органам;

- здійснює контроль за дотриманням бюджетного законодавства;

- забезпечує організацію та координацію діяльності головних бухгалтерів бюджетних установ та контроль за виконанням ними своїх повноважень шляхом проведення оцінки їхньої діяльності .

У структурі Активів, загальна сума яких станом на 01.01.2020 року склала - 108,2 млрд грн, обліковуються: гривневий еквівалент коштів на валютних рахунках у сумі 30,8 млрд грн, що становить 29\%, та кошти на єдиному казначейському рахунку (далі - ЄКР) на суму 17,5 млрд грн, що становить $16 \%$.

Крім того, в загальній сумі Активів обліковується заборгованість за позиками, наданими з ЄКР, на суму 58,2 млрд грн, або $53 \%$, зокрема:

- за позиками Пенсійного фонду України (наданими у 20072019 роках) - 49,2 млрд грн, або 45\%;

- за середньостроковими/безвідсотковими позиками (наданими місцевим бюджетам у 2009-2014 роках) - 9,0 млрд грн, 
Серія «Економічні науки»

Випуск 4(92) 2020 р.

або 8\%.

Станом на 01.01.2020 року загальна сума Пасивів склала 108,2 млрд грн. Як і у 2018 році, найбільшу частку від загальної суми коштів, що обліковується у Казначействі, складають кошти місцевих бюджетів, розпорядників та одержувачів коштів місцевих бюджетів 45,1 млрд грн, або 42\%. У порівнянні з 2018 роком залишки зазначених коштів зменшились на 3,6 млрд грн. Кошти державного бюджету становлять 32,8 млрд грн, або $30 \%$. Інші кошти клієнтів становлять 28,6 млрд грн, або 26\%, кошти позабюджетних фондів становлять 1,7 млрд грн, або $2 \%$.

Одним з основних інтегрованих показників розвитку економіки та виконання бюджету є динаміка коштів на рахунках Казначейства, які включають гривневі кошти, що обліковуються на ЄКР, та кошти на валютних рахунках, відкритих на ім'я Казначейства.

На 1 січня 2020 року на ЄKP обліковувались кошти у сумі 17,5 млрд грн. За період 2013-2019 років (станом на 1 січня кожного року) цей показник становив відповідно 0,5 млрд грн, 1,7 млрд грн, 3,0 млрд грн, 9,0 млрд грн, 14,3 млрд грн, 5,1 млрд грн та 9,9 млрд грн. Що стосується коштів на валютних рахунках Казначейства, їх гривневий еквівалент станом на 1 січня 2020 року становив 30,8 млрд грн. За період 2013-2019 років (станом на 1 січня кожного року) він складав відповідно 3,7 млрд грн, 3,2 млрд грн, 12,0 млрд грн, 35,4 млрд грн, 33,4 млрд грн, 63,5 млрд грн та 47,2 млрд грн. Таким чином, загальний обсяг коштів на рахунках Казначейства у національній валюті (гривня) та в іноземній валюті (гривневий еквівалент) станом на 1 січня 2020 року склав 48,3 млрд грн [6].

Практика бюджетних правовідносин свідчить, що протягом всього періоду функціонування державної казначейської служби України, чи ії попередника - державного казначейства України, підрозділи казначейської служби держави належним чином виконували їх функції і завдання, забезпечуючи при цьому як практичну реалізацію державної казначейсько-бюджетної політики, так і розробку напрямів їі вдосконалення. Водночас в Україні в останні роки відбувся перерозподіл бюджетних ресурсів від місцевих бюджетів до державного бюджету. Зокрема, статистичні дані свідчать, що роками через місцеві бюджети здійснюється перерозподіл лише 6-8\% ВВП та при цьому частка власних надходжень місцевих бюджетів в структурі доходів зведеного бюджету складає 25-30\% [2, С. 8].

На збільшення дохідної частини Державного бюджету України негативно впливає багато факторів, зокрема існування тіньових схем ведення бізнесу, надання податкових пільг, неузгодженість потреб у 
податкових надходженнях 3 можливостями їх отримання, недосконалість правових норм щодо забезпечення державного контролю в процесі управління ресурсами. Все це сприяє прийняттю неефективних та суб'єктивних бюджетних рішень як на стадіях складання, розгляду та затвердження бюджету, так і на стадії його виконання [1, С. 64].

Проблема дефіциту фінансових ресурсів, $\epsilon$ результатом неоптимального перерозподілу цих коштів, замість загальноприйнятого у світі управління ресурсами, яке забезпечує здійснення видатків у межах асигнувань, які реально передбачені державним та місцевими бюджетами [4, С. 129].

Ще однією проблемою ДКСУ $\epsilon$ невиразне розмежування функцій, що забезпечують бюджетне фінансування. Також, суттєвою проблемою казначейського обслуговування державного бюджету $є$ об'ємність та складність форм звітності про використання фінансових ресурсів державного бюджету, виконання бюджету та кошторисів, даний процес передбачає додаткових затрат праці від органів ДКСу. Також існує проблема кадрової плинності, що викликана сукупністю наступних чинників: занадто завищені кваліфікаційні вимоги, значне навантаження, низький рівень оплати праці, який веде до зниження мотивації до трудової діяльності тощо.

Всі окреслені проблеми є причиною недостатньо ефективного здійснення функцій підрозділів державної казначейської служби України.

3 огляду на це, необхідно здійснити ряд заходів для вирішення виявлених проблем, а саме [5, С. 58-60]:

1. Ефективніше використовувати залишки коштів на ЄKР, які тимчасово вільні.

2. Посилити діяльність органів ДКСУ, пов'язаної з випуском державних цінних паперів.

3. Чітко розділити функції і повноваження, що стосується використання бюджетних коштів між органами ДКСу та Міністерством фінансів України.

4. Збільшити повноваження органів казначейства в частині посилення контролю за витрачанням бюджетних коштів.

5. Виокремити кошти 3 державного бюджету розпорядникам коштів на основі їх реальних потреб.

6. Вдосконалити нормативно-законодавчу базу, що регулює процес казначейського обслуговування державного бюджету.

7. Спрощення форм звітності та механізму її подання до органів ДКСу. 
Серія «Економічні науки»

Випуск 4(92) 2020 p.

8. Вирішити кадрові проблеми шляхом покращення умов праці, фінансування, а також підвищення кваліфікаційного рівня працівників.

Висновки. Для розвитку системи ДКСУ необхідно удосконалити існуючі та створення нових механізмів у напрямі зосередження та централізації фінансових ресурсів в єдиній структурі органів Державної казначейської служби України та посиленні контрольних функцій з боку держави за своєчасним і повним надходженням до бюджету. Важливо продовжувати запровадження інноваційних проєктів казначейства, зокрема оптимізацію кількості учасників Системи електронних платежів Національного банку України територіальних органів Казначейства, шляхом подальшої централізації інформаційних ресурсів Казначейства; запровадження з 1 січня 2020 року в системі Казначейства Плану рахунків бухгалтерського обліку в державному секторі; подальшу реалізацію системи подання електронної звітності розпорядниками та одержувачами бюджетних коштів і державними цільовими фондами («€-Звітність»); запровадження ЄР на балансі Казначейства для зарахування митних платежів; Угоди про інформаційний обмін між ЦОВВ (центральні органи виконавчої влади).

1. Боровик П. М., Козлова І.М., Кодола М. Ю. Казначейське виконання місцевих бюджетів: проблеми та шляхи їх вирішення. Теоретичні та практичні аспекти стійкого розвитку фінансової системи України : кол. моногр. / за ред. 0. О. Непочатенко. Умань: Видавн.-поліграф. центр «Візаві», 2015. Ч. 1. С. 63-67. 2. Прядко В. В. Проблеми формування доходної частини місцевих бюджетів та шляхи їх розв'язання. Науковий вісник Буковинської державної фінансової академії: 3б. наук. праць. Економічні науки. 2010. Вип. 1 (18). С. 6-12. 3. Офіційний вебсайт електронних ресурсів НБУВ (Розділи: Наукова періодика України, Автореферати дисертацій). URL: http://www.nbuv.gov.ua/node/2116. (дата звернення: 20.11.2020). 4. Блошинська А.В. Казначейська система касового виконання Державного бюджету України та напрями ї̈ вдосконалення. Науковий вісник Волинського національного університету імені Лесі Українки. Фінанси. 2014. Вип. № 7. С. 127-132. 5. Гріщенко І. В. Організаційно-методичні засади фінансового контролю формування і використання коштів загального і спеціального фондів кошторису бюджетної установи. Обліково-аналітичне та фінансове забезпечення управління підприємства: міжнародний досвід та вітчизняна практика: зб. наук. праць всеукраїнської науково-практичної Інтернет-конференції. Вінниця: Центр підготовки навчально-методичних видань ВТЕІ КНТЕУ, 2011. С. 58-60. 6. Публічний звіт голови Казначейства Тетяни Слюз про підсумки діяльності Державної казначейської служби України за 2019 рік. URL: https://www.treasury.gov.ua/storage/app/sites/1/uploadedfiles $/ \% 20 \%$ D0\%93\%D0\%9E\%D0\%9B\%D0\%9E\%D0\%92\%D0\%98\%202020pdf.pdf (дата звернення: 20.11.2020). 


\section{REFERENCES:}

1. Borovyk P. M., Kozlova I. M., Kodola M. Yu. Kaznacheiske vykonannia mistsevykh biudzhetiv: problemy ta shliakhy yikh vyrishennia. Teoretychni ta praktychni aspekty stiikoho rozvytku finansovoi systemy Ukrainy : kol. monohr. / pid red. 0. 0. Nepochatenko. Uman : Vydavn.-polihraf. tsentr «Vizavi», 2015. Ch. 1. S. 63-67. 2. Priadko V. V. Problemy formuvannia dokhodnoi chastyny mistsevykh biudzhetiv ta shliakhy yikh rozviazannia. Naukovyi visnyk Bukovynskoi derzhavnoi finansovoi akademii : zb. nauk. prats. Ekonomichni nauky. 2010. Vyp. 1 (18). S. 6-12. 3. Ofitsiinyi vebsait elektronnykh resursiv NBUV (Rozdily: Naukova periodyka Ukrainy, Avtoreferaty dysertatsii). URL: http://www.nbuv.gov.ua/node/2116. (data zvernennia: 20.11.2020). 4. Bloshynska A. V. Kaznacheiska systema kasovoho vykonannia Derzhavnoho biudzhetu Ukrainy ta napriamy yii vdoskonalennia. Naukovyi visnyk Volynskoho natsionalnoho universytetu imeni Lesi Ukrainky. Finansy. 2014. Vyp. № 7. S. 127-132. 5. Hrishchenko I. V. Orhanizatsiino-metodychni zasady finansovoho kontroliu formuvannia i vykorystannia koshtiv zahalnoho i spetsialnoho fondiv koshtorysu biudzhetnoi ustanovy. Oblikovo-analitychne ta finansove zabezpechennia upravlinnia pidpryiemstva: mizhnarodnyi dosvid ta vitchyzniana praktyka : zb. nauk. prats vseukrainskoi naukovo-praktychnoi Internet-konferentsii. Vinnytsia : Tsentr pidhotovky navchalno-metodychnykh vydan VTEI KNTEU, 2011. S. 58-60. 6. Publichnyi zvit holovy kaznacheistva Tetiany Sliuz pro pidsumky diialnosti Derzhavnoi kaznacheiskoi sluzhby Ukrainy za 2019 rik. URL: https://www.treasury.gov.ua/storage/app/sites/1/uploadedfiles $/ \% 20 \%$ D0\%93\%D0\%9E\%D0\%9B\%D0\%9E\%D0\%92\%D0\%98\%202020pdf.pdf (data zvernennia: 20.11.2020).

Fedyna K. M. [1; ORCID ID: 0000-0001-5571-384X], Candidate of Economics (Ph.D.), Associate Professor

${ }^{1}$ National University of Water and Environmental Enginerring, Rivne

\section{PROBLEMS AND WAYS OF IMPROVING THE TREASURY SYSTEM OF CASH EXECUTION OF BUDGETS}

The article examines the essence of the treasury service and its main role in the budget process. The problems of the activity of the State Treasury Service are analyzed. A list of measures to improve the performance of the treasury system for budget execution is proposed. Establishment of the treasury service and the structure of assets and passives has been analyzed. One of the main integrated indicators of economic development and budget execution is the dynamics of funds in the Treasury accounts, which include hryvnia funds accounted for on the ECR and funds in foreign currency accounts opened in the name of the Treasury.

The problems of the efficiency of the State Treasury Service have been analyzed. The practice of budgetary legal relations shows that during the whole period of functioning of the State Treasury Service of Ukraine, or its 
predecessor, units of the State Treasury Service properly performed their functions and tasks, ensuring both practical implementation of state treasury and budget policy. At the same time, in Ukraine in recent years there has been a redistribution of budget resources from local budgets to the state budget.

For the development of the STSU system it is necessary to improve the existing and create new mechanisms in the direction of concentration and centralization of financial resources in a single structure of the State Treasury Service of Ukraine and strengthening control functions by the state for timely and full budget revenues. It is important to continue the introduction of innovative projects of the Treasury, in particular the optimization of the number of participants in the Electronic Payment System of the National Bank of Ukraine - territorial bodies of the Treasury, by further centralization of information resources of the Treasury; introduction from January 1, 2020 in the system of the Treasury of the Chart of Accounts in the public sector; further implementation of the system of electronic reporting by managers and recipients of budget funds and state trust funds (e-reporting); introduction of a single account on the balance of the Treasury for crediting customs payments; agreements on information exchange between CEBs (central executive bodies).

Keywords: financial policy; treasury system; budget; Ministry of Finance of Ukraine; financial security; single treasury account; assets and passive.

Федина К. М. ${ }^{[1 ;}$ ORCID ID: 0000-0001-5571-384X], к.э.н., доцент

${ }^{1}$ Национальный университет водного хозяйства и природопользования, г. Ровно

\section{ПРОБЛЕМЫ И ПУТИ СОВЕРШЕНСТВОВАНИЯ КАЗНАЧЕЙСКОЙ СИСТЕМЫ КАССОВОГО ИСПОЛНЕНИЯ БЮДЖЕТОВ}

В статье исследована сущность казначейской службы и ее основная роль в бюджетном процессе. Проанализированы проблемы деятельности Государственной казначейской службы. Предложен перечень мероприятий по улучшению деятельности казначейской системы исполнения бюджетов.

Ключевые слова: финансовая политика; казначейская система; бюджет; Министерство финансов Украины; финансовая безопасность; ЕКС; активы и пассивы. 